\title{
Aktivitas Antioksidan Ekstrak Metanol Biji Langsat (Lansium domesticum var. pubescens) dan Duku (Lansium domesticum var. domesticum) dengan Metode DPPH
}

\author{
Josepin P Konda ${ }^{1)}$, Jainer P Siampa ${ }^{1)}$, Trina E Tallei ${ }^{2)}$, \\ Billy J Kepel $^{3)}$, Fatimawali Fatimawali ${ }^{\left.{ }^{*}\right)}$ \\ ${ }^{1)}$ Program Studi Farmasi Fakultas Matematika dan Ilmu Pengetahuan Alam \\ Universitas Sam Ratulangi, Manado \\ ${ }^{2)}$ Program Studi Biologi Fakultas Fakultas Matematika dan Ilmu Pengetahuan Alam \\ Universitas Sam Ratulangi, Manado \\ ${ }^{3)}$ Fakultas Kedokteran Universitas Sam Ratulangi, Manado \\ "Coresponding author: fatimawali@ unsrat.ac.id
}

(Article History: Received 15-06-2020; Accepted 18-08-2020; Published 08-10-2020)

\begin{abstract}
ABSTRAK
Penelitian ini bertujuan untuk mengetahui kandungan fitokimia dan aktivitas antioksidan ekstrak biji langsat dan duku dengan metode DPPH. Biji buah langsat dan buah duku diekstraksi menggunakan metode maserasi dengan pelarut metanol. Skrining fitokimia yang dilakukan meliputi uji alkaloid, flavonoid, tannin, triterpenoid, steroid dan saponin secara kualitatif dengan metode uji warna. Uji aktivitas antioksidan menggunakan metode DPPH dan vitamin C sebagai pembanding, serapan diukur menggunakan spektrofotometer UV-Vis pada panjang gelombang $517 \mathrm{~nm}$. Skrining fitokimia pada ekstrak metanol biji langsat menunjukkan hasil positif terhadap alkaloid, triterpenoid dan saponin, sementara pada ekstrak metanol biji duku menunjukkan hasil positif terhadap alkaloid, flavonoid, tannin, triterpenoid, steroid dan saponin. Aktivitas antioksidan ekstrak biji langsat dianalisis menggunakan persamaan garis regresi $\mathrm{Y}=33,143+$ 0,2922X, diperoleh $\mathrm{IC}_{50} 57,69 \mu \mathrm{g} / \mathrm{mL}$. Sedangkan aktivitas antioksidan ekstrak biji duku dianalisis menggunakan persamaan garis regresi $\mathrm{Y}=29,421+0,6554 \mathrm{X}$, diperoleh $\mathrm{IC}_{50} 31,40$ $\mu \mathrm{g} / \mathrm{mL}$ dan pembanding vitamin $\mathrm{C}$ diperoleh $\mathrm{IC}_{50} 8,03 \mu \mathrm{g} / \mathrm{mL}$. Hasil penelitian ini dapat disimpulkan bahwa ekstrak metanol biji buah langsat memiliki kandungan alkaloid, triterpenoid dan saponin serta memiliki aktivitas antioksidan yang kuat sedangkan ekstrak metanol biji buah duku memiliki kandungan alkaloid, flavonoid, tannin, triterpenoid dan saponin serta memiliki aktivitas antioksidan yang sangat kuat.
\end{abstract}

Kata Kunci: Antioksidan, biji duku, biji langsat

\section{Antioxidant Activity of Methanol Extract of Langsat Seeds (Lansium domesticum var. pubescens) and Duku Seeds (Lansium domesticum var.domesticum) by Using DPPH Method}

\begin{abstract}
This study aimed to determine the phytochemical content and antioxidant activity of langsat seed extract and duku seed extract by using the DPPH method. Langsat seeds and duku seeds were extracted by using maceration method with methanol as the solvent. Phytochemical screening was carried out including a qualitative test of alkaloids, flavonoids, steroids/triterpenoids, saponins, and tannins by using the color test method. Antioxidant activity was tested by using the DPPH method and vitamin $\mathrm{C}$ used as comparison, the absorption was measured by using UV-Vis spectrophotometer at $517 \mathrm{~nm}$ wavelength. The result of phytocemical screening on methanol extract of langsat seeds showed positive results on alkaloids, triterpenoids, and saponins, meanwhile methanol extract of duku seeds showed positive results on alkaloids, flavonoids, triterpenoids, tannin and saponins. The antioxidant activity of methanol extract of langsat seeds was analyzed by using the equation of the regression line $\mathrm{Y}=33,143+0,2922 \mathrm{X}$, which obtained $\mathrm{IC}_{50}$ value of $57.69 \mu \mathrm{g} / \mathrm{mL}$. Meanwhile, the antioxidant activity of methanol extract of duku seeds
\end{abstract}


was analyzed by using the equation of the regression line $\mathrm{Y}=29,421+0,6554 \mathrm{X}$, obtained $\mathrm{IC}_{50}$ $31,40 \mu \mathrm{g} / \mathrm{mL}$. Vitamin C obtained $\mathrm{IC}_{50} 8.03 \mu \mathrm{g} / \mathrm{mL}$. On the basis of all results, it can be concluded that the methanol extract of langsat seeds contained alkaloids, saponins and triterpenoid and has a strong antioxidant activity. Meanwhile, the methanol extract of duku seeds contained alkaloids, flavonoids, triterpenoids, tannin and saponins and has a very strong antioxidant activity.

Keywords: Antioxidants, duku seeds, langsat seeds

\section{PENDAHULUAN}

Dalam kehidupan sehari-hari, kita tidak dapat terbebas dari senyawa radikal bebas. Sumber pembentuk radikal bebas antara lain asap rokok, makanan yang digoreng dan dibakar, paparan sinar matahari berlebih, asap kendaraan bermotor, obat-obat tertentu, racun dan polusi udara (Umayah \& Amrun, 2007). Radikal bebas adalah suatu atom atau molekul yang mempunyai elektron tidak berpasangan. Radikal bebas dapat masuk ke dalam tubuh dan menyerang sel-sel yang sehat dan menyebabkan sel-sel tersebut kehilangan fungsi dan strukturnya (Liochev, 2013).

Efek negatif radikal bebas terhadap tubuh dapat dicegah dengan senyawa yang disebut antioksidan. Antioksidan memiliki kemampuan memberikan elektron, mengikat dan mengakhiri reaksi berantai radikal bebas (Halliwell, 2012). Antioksidan merupakan senyawa yang dapat menstabilkan radikal bebas dalam melengkapi kekurangan elektron yang dimiliki radikal bebas dan menghambat terjadinya reaksi berantai dari pembentukan radikal bebas (Selawa et al., 2013).

Untuk menguji adanya aktivitas antioksidan dapat menggunakan metode DPPH (1,1-diphenyl-2-picrylhydrazyl). Pengamatan terhadap penangkapan radikal DPPH dapat dilakukan dengan mengamati penurunan absorbansi ( $\mathrm{Yu}$ et al., 2002). Parameter yang digunakan untuk penangkapan radikal DPPH adalah $\mathrm{IC}_{50}$ yaitu konsentrasi ekstrak atau fraksi uji yang dibutuhkan untuk menangkap radikal DPPH sebanyak 50\% (Zou et al., 2004).

Langsat merupakan salah satu tanaman obat yang dapat dijumpai di Indonesia. Beberapa bagian dari langsat banyak dimanfaatkan oleh masyarakat antara lain untuk mengobati berbagai penyakit, antara lain sebagai obat cacing, obat demam, obat diare, dan bahkan kulit batang juga sebagai anti kanker (Mokosuli, 2008).

Duku termasuk jenis buah tropis yang dikenal di Indonesia, sangat digemari karena rasanya yang manis dan aromanya yang enak. Duku memiliki kandungan gizi dan serat (dietary fiber) yang tinggi dan sangat bermanfaat untuk memperlancar pencernaan dan mencegah kanker usus besar (colon) (Zulkarnain, 2017). Rasa pahit pada biji sering dikaitkan dengan senyawa antioksidan yang dikandungnya yang dapat mencegah serangan radikal bebas, sehingga dapat menurunkan risiko penyakit jantung, diabetes dan kanker.

Sebagai salah satu upaya untuk mengoptimalkan pemanfaatan bahan alam hayati Indonesia, maka perlu dilakukan penelitian dengan tujuan untuk menguji aktivitas antioksidan ekstrak biji duku dan langsat. Pengungkapan potensinya sebagai sumber antioksidan berkaitan dengan senyawa kimia yang dikandungnya sehingga perlu dilakukan skrining fitokimia.

\section{METODE PENELITIAN}

\section{Waktu dan Tempat Penelitian}

Penelitian ini dilaksanakan pada bulan Desember 2019 sampai dengan bulan April 2020 di Laboratorium advance (lanjut) Program Studi Farmasi, Universitas Sam Ratulangi, Manado.

\section{Jenis Penelitian}

Penelitian ini merupakan penelitian eksperimental laboratorium.

\section{Alat dan Bahan}

Alat-alat yang digunakan dalam penelitian ini adalah timbangan analitik, oven, blender, alumuium foil, toples, corong, ayakan, kertas saring, vacuum evaporator, beaker glass, labu takar, pipet tetes, mikropipet, tabung reaksi, rak tabung, gelas ukur, batang pengaduk, hotplate dan spektrofotometer UV-Vis.

Bahan yang digunakan dalam penelitian ini yaitu biji duku (Lansium domesticum var. domesticum), biji langsat (Lansium domesticum var. pubescens), vitamin $\mathrm{C}$ p.a, metanol, $\mathrm{CH}_{3} \mathrm{COOH}$ glasial, aquades, $\mathrm{FeCl}_{3}$, pereaksi Mayer, pereaksi 
Dragendorf, pereaksi Wagner, amonia, asam klorida, serbuk magnesium, asam sulfat, etanol $96 \%$, kloroform dan 1,1-diphenyl-2picrylhydrazyl (DPPH) (Sigma-Aldrich).

\section{Penyiapan Sampel}

Biji duku dan langsat dipisahkan dari kulit dan daging buahnya, dicuci bersih dibawah air mengalir. Sampel biji langsat dan biji duku diangin-anginkan selama 3 hari dan dikeringkan dalam oven dengan suhu $40^{\circ} \mathrm{C}$ hingga kadar airnya berkurang hingga mencapai 5\%. Biji langsat dan duku yang kering dihaluskan dengan blender, kemudian diayak dengan ayakan mesh 40 .

\section{Identifikasi Tumbuhan}

Identifikasi tumbuhan dilakukan di Laboratorium Taksonomi Tumbuhan Program Studi Biologi Fakultas Matematika dan Ilmu Pengetahuan Alam, Universitas Sam Ratulangi.

\section{Ekstraksi}

Sebanyak 300 g serbuk kering simplisia ditambahkan pelarut metanol sebanyak $900 \mathrm{~mL}$ dan dibiarkan terendam selama 5 hari terlindung dari cahaya. Selama perendaman dilakukan pengadukan setiap hari. Ekstrak kemudian disaring dengan menggunakan kertas saring kemudian residunya dimaserasi dengan metanol sebanyak $450 \mathrm{~mL}$ menggunakan prosedur yang sama, maserasi dilakukan selama 2 hari. Selanjutnya maserat metanol dipekatkan menggunakan oven pada suhu $40^{\circ} \mathrm{C}$ sampai diperoleh ekstrak kental.

\section{Skrining Fitokimia}

Skrining fitokimia yang dilakukan meliputi uji alkaloid, flavonoid, tannin, triterpenoid, steroid dan saponin yang berdasar pada metode Harborne.

a. Pemeriksaan Alkaloid

Sebanyak 0,2 gram ekstrak dimasukkan dalam tabung reaksi kemudian ditambahkan kloroform secukupnya, selanjutnya ditambahkan $5 \mathrm{~mL}$ amonia dan 5 $\mathrm{mL}$ kloroform lalu ditambahkan 10 tetes $\mathrm{H}_{2} \mathrm{SO}_{4} 2 \mathrm{~N}$. Campuran dikocok dan dibiarkan hingga membentuk 2 lapisan. Lapisan atas dipindahkan dalam 3 tabung reaksi dengan volume masing-masing $1 \mathrm{~mL}$. Kemudian masing-masing tabung tersebut ditambahkan beberapa tetes pereaksi Mayer, Wagner dan Dragendorff. Apabila terbentuk endapan menunjukkan bahwa sampel tersebut mengandung alkaloid, dengan pereaksi Mayer memberikan endapan putih, dengan pereaksi Wagner memberikan endapan berwarna coklat dan pereaksi Dragendorff memberikan endapan berwarna jingga.

b. Pemeriksaan Flavonoid

Sebanyak 0,2 gram ekstrak dimasukkan dalam tabung reaksi, ditambahkan $5 \mathrm{~mL}$ etanol dan dipanaskan selama 5 menit dalam tabung reaksi. Selanjutnya ditambahkan beberapa tetes $\mathrm{HCl}$ pekat. Kemudian ditambahkan 0,2 gram serbuk Mg. Adanya flavonoid ditunjukkan oleh timbulnya warna merah tua.

c. Pemeriksaan Tanin

Sebanyak 0,2 gram ekstrak ditambahkan dengan etanol secukupnya. Kemudian ditambahkan 2-3 tetes larutan $\mathrm{FeCl}_{3} 1 \%$. Hasil positif ditunjukkan dengan terbentuknya warna hitam kebiruan atau hijau.

d. Pemeriksaan Steroid dan Triterpenoid

Sebanyak 0,2 gram ekstrak ditambahkan $\mathrm{CH}_{3} \mathrm{COOH}$ glasial secukupnya, dibiarkan selama 15 menit kemudian 6 tetes larutan dipindahkan ke dalam tabung reaksi dan ditambahkan 2-3 tetes $\mathrm{H}_{2} \mathrm{SO}_{4}$ pekat. Adanya triterpenoid ditunjukkan dengan terjadinya perubahan warna menjadi warna merah atau ungu, sedangkan steroid ditunjukkan dengan terjadinya perubahan warna menjadi warna biru atau hijau.

e. Pemeriksaan Saponin

Sebanyak 0,2 gram ekstrak ditambahkan dengan akuades secukupnya kemudian didihkan 2-3 menit. Selanjutnya didinginkan dan dikocok kuat. Hasil positif ditunjukkan dengan terbentuknya buih yang stabil.

\section{Pembuatan Larutan DPPH}

Serbuk DPPH sebanyak $4 \quad \mathrm{mg}$ dilarutkan dengan metanol hingga mencapai $100 \mathrm{~mL}$ dalam labu ukur. Larutan dijaga pada suhu kamar, terlindung dari cahaya untuk segera digunakan.

\section{Pengukuran Larutan Kontrol DPPH}

Pengukuran dilakukan dengan memipet $1 \mathrm{ml}$ larutan DPPH lalu ditambahkan dengan larutan ekstrak hingga volume $5 \mathrm{ml}$ dan dicukupkan volumenya sampai $5 \mathrm{ml}$. Campuran dikocok dan dibiarkan selama 30 menit pada suhu kamar kemudian diukur absorbansinya pada panjang 
gelombang $517 \mathrm{~nm}$, dilakukan sebanyak 3 replikasi.

\section{Pengukuran Aktivitas Antioksidan Sampel}

Sebanyak $10 \mathrm{mg}$ ekstrak dilarutkan dengan metanol dalam labu takar $10 \mathrm{~mL}$ sampai batas, diperoleh larutan stok dengan konsentrasi $1000 \mu \mathrm{g} / \mathrm{mL}$. Dibuat masingmasing konsentrasi $5 \mu \mathrm{g} / \mathrm{mL}, 10 \mu \mathrm{g} / \mathrm{mL}, 15$ $\mu \mathrm{g} / \mathrm{mL}, 20 \mu \mathrm{g} / \mathrm{mL}$ dan $25 \mu \mathrm{g} / \mathrm{mL}$ sebanyak 5 $\mathrm{mL}$.

Pada masing-masing konsentrasi dipipet sebanyak $1 \mathrm{~mL}$ dimasukkan ke dalam tabung reaksi dan ditambahkan $2 \mathrm{~mL}$ larutan DPPH sehingga larutan menjadi $3 \mathrm{~mL}$ kemudian divortex selama 5 detik dan dibiarkan selama 30 menit pada suhu kamar. Masing-masing larutan tersebut diukur serapannya pada panjang gelombang $517 \mathrm{~nm}$, dilakukan sebanyak 3 replikasi.

\section{Pengukuran Aktivitas Antioksidan Vitamin C}

Ditimbang vitamin C p.a sebanyak 10 mg kemudian dilarutkan dengan metanol 10 $\mathrm{ml}$, diperoleh larutan stok dengan konsentrasi $1000 \mu \mathrm{g} / \mathrm{mL}$. Dari larutan stok masingmasing dipipet $25 \mu \mathrm{L}, 50 \mu \mathrm{L}, 75 \mu \mathrm{L}, 100 \mu \mathrm{L}$ dan $125 \mu \mathrm{L}$, kemudian ditambahkan metanol hingga $5 \mathrm{~mL}$ sehingga diperoleh masingmasing konsentrasi $5 \mu \mathrm{g} / \mathrm{mL}, 10 \mu \mathrm{g} / \mathrm{mL}, 15$ $\mu \mathrm{g} / \mathrm{mL}, \quad 20 \mu \mathrm{g} / \mathrm{mL}$ dan $25 \mu \mathrm{g} / \mathrm{mL}$. Pada masing-masing konsentrasi dipipet $1 \mathrm{~mL}$ dan dimasukan ke dalam tabung reaksi kemudian ditambahkan $2 \mathrm{~mL}$ larutan DPPH. Setelah itu, divortex selama 5 detik dan dibiarkan selama 30 menit pada suhu kamar. Masing-masing larutan tersebut diukur serapannya pada panjang gelombang $517 \mathrm{~nm}$, dilakukan sebanyak 3 replikasi.

\section{Penentuan Nilai Inhibitory Concentration $50\left(\right.$ IC $\left._{\mathbf{5 0}}\right)$}

Parameter yang bisa digunakan untuk menginterprestasikan hasil dari uji aktivitas antioksidan dengan metode DPPH adalah dengan nilai $\mathrm{IC}_{50}$, yaitu konsentrasi yang menyebabkan hilangnya $50 \%$ aktivitas DPPH. Untuk menghitung nilai $\mathrm{IC}_{50}$ diperlukan data persen inhibisi dari pengujian yang dilakukan. Persen inhibisi dapat dihitung dengan menggunakan rumus sebagai berikut:

$\%$ inhibisi $=\frac{\text { absorbansi blanko }- \text { absorbansi sampel }}{\text { absorbansi blanko }} \times 100 \%$
Konsentrasi sampel dan persen inhibisi yang diperoleh diplot masing-masing pada sumbu x dan y pada persamaan regresi linear. Persamaan tersebut digunakan untuk menentukan $\mathrm{IC}_{50}$ dari masing-masing sampel dinyatakan dengan nilai y sebesar 50 dan nilai $\mathrm{x}$ yang akan diperoleh sebagai $\mathrm{IC}_{50}$ (Molyneux, 2004). Suatu senyawa memiliki antioksidan yang sangat kuat bila nilai $\mathrm{IC}_{50}<$ $50 \mu \mathrm{g} / \mathrm{mL}$, kuat bila nilai IC S0 $_{50}$ bernilai $50-100$ $\mu \mathrm{g} / \mathrm{mL}$, sedang bila nilai $\mathrm{IC}_{50}$ bernilai 100$150 \mu \mathrm{g} / \mathrm{mL}$, dan lemah bila nilai IC $_{50}$ bernilai $151-200 \mu \mathrm{g} / \mathrm{mL}$ (Blois, 2005).

\section{HASIL DAN PEMBAHASAN}

\section{Ekstraksi}

Proses ekstraksi simplisia biji duku dan langsat dilakukan dengan metode maserasi dengan sistem remaserasi atau maserasi berulang. Metode maserasi sangat menguntungkan dalam isolasi senyawa bahan alam karena dengan perendaman sampel tumbuhan akan terjadi pemecahan dinding dan membran sel akibat perbedaan tekanan antara di dalam dan di luar sel sehingga metabolit sekunder yang ada dalam sitoplasma akan terlarut dalam pelarut organik dan ekstraksi senyawa akan sempurna karena dapat diatur lama perendaman yang dilakukan (Lenny, 2006).

Metanol merupakan pelarut universal yang memiliki gugus polar $(-\mathrm{OH})$ dan gugus non polar $\left(-\mathrm{CH}_{3}\right)$ sehingga dapat menarik analit-analit yang bersifat polar dan non polar (Watson, 2009). Tujuan dilakukannya remaserasi adalah untuk menyari senyawasenyawa yang masih tertinggal atau tidak tersari. Filtrat hasil maserasi disaring, dikumpulkan dan kemudian pelarutnya diuapkan sehingga diperoleh ekstrak kental biji langsat dan duku dengan rendemen 7,2\% dan $8,1 \%$.

\section{Skrining Fitokimia}

Skrining fitokimia bertujuan untuk mengetahui kandungan senyawa fitokimia pada ekstrak metanol biji langsat secara kualitatif. Senyawa fitokimia yang diidentifikasi meliputi, senyawa alkaloid, senyawa flavonoid, senyawa tanin, senyawa triterpenoid, senyawa steroid dan senyawa saponin berdasarkan McMurray \& Fay (2004) dengan hasil yang positif jika 
memperlihatkan hasil reaksi seperti pada Tabel 1 dan Tabel 2.

Tabel 1. Hasil Skrining Fitokimia Ekstrak Biji Buah Langsat

\begin{tabular}{llc}
\hline $\begin{array}{c}\text { Senyawa } \\
\text { Metabolit } \\
\text { sekunder }\end{array}$ & $\begin{array}{l}\text { Hasil Positif } \\
\text { Menurut pustaka }\end{array}$ & $\begin{array}{c}\text { Hasil } \\
\text { Penelitian }\end{array}$ \\
\hline $\begin{array}{l}\text { Alkaloid : } \\
\text { - Mayer }\end{array}$ & $\begin{array}{l}\text { Terbentuk endapan } \\
\text { putih }\end{array}$ & + \\
- Wagner & $\begin{array}{l}\text { Terbentuk } \\
\text { endapan coklat }\end{array}$ & + \\
- Dragendorf & $\begin{array}{l}\text { Terbentuk } \\
\text { endapan jingga }\end{array}$ & + \\
Flavonoid & $\begin{array}{l}\text { Terbentuk warna } \\
\text { merah tua }\end{array}$ & - \\
Tanin & $\begin{array}{l}\text { Terbentuk warna } \\
\text { hitam kebiruan } \\
\text { atau hijau }\end{array}$ & - \\
Triterpenoid & $\begin{array}{l}\text { Terbentuk warna } \\
\text { merah atau ungu }\end{array}$ & + \\
Steroid & $\begin{array}{l}\text { Terbentuk warna } \\
\text { biru atau hijau } \\
\text { Terbentuk buih } \\
\text { stabil }\end{array}$ & - \\
Saponin & & + \\
\hline
\end{tabular}

Hasil pengujian fitokimia pada Tabel 1 yang telah dilakukan menunjukkan bahwa ekstrak biji langsat memiliki kandungan metabolit sekunder berupa alkaloid, triterpenoid dan saponin.

Tabel 2. Hasil Skrining Fitokimia Ekstrak Biji Buah Duku

\begin{tabular}{|c|c|c|}
\hline $\begin{array}{c}\text { Senyawa } \\
\text { Metabolit } \\
\text { sekunder } \\
\end{array}$ & $\begin{array}{l}\text { Hasil Positif } \\
\text { Menurut pustaka }\end{array}$ & $\begin{array}{c}\text { Hasil } \\
\text { Penelitian }\end{array}$ \\
\hline $\begin{array}{l}\text { Alkaloid : } \\
\text { - Mayer }\end{array}$ & $\begin{array}{l}\text { Terbentuk endapan } \\
\text { putih }\end{array}$ & + \\
\hline - Wagner & $\begin{array}{l}\text { Terbentuk } \\
\text { endapan coklat }\end{array}$ & + \\
\hline - Dragendorf & $\begin{array}{l}\text { Terbentuk } \\
\text { endapan jingga }\end{array}$ & + \\
\hline Flavonoid & $\begin{array}{l}\text { Terbentuk warna } \\
\text { merah tua }\end{array}$ & + \\
\hline Tanin & $\begin{array}{l}\text { Terbentuk warna } \\
\text { hitam kebiruan } \\
\text { atau hijau }\end{array}$ & + \\
\hline Triterpenoid & $\begin{array}{l}\text { Terbentuk warna } \\
\text { merah atau ungu }\end{array}$ & + \\
\hline Steroid & $\begin{array}{l}\text { Terbentuk warna } \\
\text { biru atau hijau }\end{array}$ & - \\
\hline Saponin & $\begin{array}{l}\text { Terbentuk buih } \\
\text { stabil }\end{array}$ & + \\
\hline
\end{tabular}

Hasil pengujian fitokimia pada Tabel 2 yang telah dilakukan menunjukkan bahwa ekstrak biji duku memiliki kandungan metabolit sekunder berupa alkaloid, flavonoid, tanin, triterpenoid dan saponin.

Uji alkaloid, ekstrak biji langsat dan biji duku menunjukkan hasil positif pada pereaksi Mayer, Wagner dan Dragendorff. Prinsip yang digunakan pada uji alkaloid yaitu reaksi pengendapan yang terjadi karena adanya penggantian logam. Atom nitrogen yang memiliki pasangan elektron bebas sehingga dapat digunakan untuk membentuk ikatan kovalen koordinat dengan ion logam. Hasil ini diperkuat oleh penelitian Tanwirotun, 2015, yang menemukan senyawa alkaloid, flavonoid dan saponin dalam ekstrak biji duku.

Uji flavonoid positif pada ekstrak biji duku. Penambahan $\mathrm{HCl}$ pekat pada uji flavonoid digunakan untuk menghidrolisis flavonoid menjadi aglikonnya, yaitu dengan menghidrolisis O-glikosil. Glikosil akan tergantikan oleh $\mathrm{H}^{+}$dari asam karena sifatnya yang elektrofilik. Glikosida berupa gula yang biasa dijumpai yaitu glukosa, galaktosa dan raminosa. Menurut Robinson (1995), warna merah yang dihasilkan menandakan adanya flavonoid akibat dari reduksi oleh asam klorida dan magnesium.

Uji tanin positif pada ekstrak biji duku, dilakukan dengan penambahan $\mathrm{FeCl} 3$ yang bereaksi dengan salah satu gugus hidroksil yang ada pada tanin. Fungsi $\mathrm{FeCl} 3$ adalah menghidrolisis golongan tanin sehingga menghasilkan perubahan warna biru kehitaman dan tanin terkondensasi yang menghasilkan warna hijau kehitaman. Kandungan tanin juga terdapat pada biji alpukat (Malangngi et al., 2012).

Uji triterpenoid positif pada ekstrak biji langsat dan duku. Penambahan $\mathrm{H}_{2} \mathrm{SO}_{4}$ pekat mengakibatkan terjadinya reaksi antara anhidrida asetat dengan asam sehingga atom C pada anhidrida membentuk karbokation. Karbokation yang terbentuk bereaksi dengan atom $\mathrm{O}$ pada gugus $-\mathrm{OH}$ yang ada pada senyawa triterpenoid. Reaksi ini merupakan reaksi esterifikasi yaitu pembentukan senyawa ester oleh senyawa triterpenoid dengan anhidrida asetat. Selain pada biji langsat dan biji duku yang ditemukan dalam penelitian ini, triterpenoid juga terdapat pada daun dan kulit batang duku (Aldi, 2013; Darma, 2014). Menurut Robinson (1995), 
berbagai macam aktivitas fisiologis yang menarik ditunjukkan oleh beberapa triterpenoid, dan senyawa ini merupakan komponen aktif dalam tumbuhan obat yang telah digunakan untuk mengobati penyakit termasuk diabetes, kerusakan hati dan malaria.

Uji saponin positif pada ekstrak biji langsat dan duku karena terbentuk busa yang stabil. Menurut Robinson (1995), senyawa yang memiliki gugus polar dan non polar bersifat aktif permukaan sehingga saat saponin dikocok dengan air dapat membentuk misel. Pada struktur misel, gugus polar menghadap ke luar sedangkan gugus non polarnya menghadap ke dalam, keadaan inilah yang tampak seperti busa. Kandungan alkaloid, flavonoid, tanin, triterpenoid, steroid dan saponin pada biji duku, hal yang sama juga ditemukan pada biji alpukat oleh Kopon et al. (2020).

\section{Uji Antioksidan}

Pengujian aktivitas antioksidan pada sampel dilakukan dengan metode DPPH. Prinsip dari metode ini adalah mengukur aktivitas antioksidan secara kuantitatif yaitu dengan pengukuran aktivitas perendaman radikal DPPH oleh ekstrak menggunakan spektrofotometer UV-Vis dengan panjang gelombang $517 \mathrm{~nm}$ sehingga akan diketahui nilai aktivitas perendaman radikal bebas yang dinyatakan dengan nilai $\mathrm{IC}_{50}$. Panjang gelombang $517 \mathrm{~nm}$ merupakan panjang gelombang maksimum DPPH. Menurut Rizkayanti et al. (2017), panjang gelombang maksimum akan memberikan serapan paling optimal dari larutan uji dan memberikan kepekaan yang paling besar, sehingga diharapkan dapat diperoleh nilai absorbansi yang optimal pada sampel.

Sampel yang diuji aktivitas antioksidannya adalah ekstrak metanol biji langsat, ekstrak metanol biji duku dan vitamin $\mathrm{C}$ sebagai pembanding. Vitamin $\mathrm{C}$ digunakan karena berfungsi sebagai antioksidan yaitu menangkap radikal bebas dan mencegah terjadinya reaksi berantai. Menurut Triyem (2010), vitamin C mempunyai gugus hidroksi bebas yang bertindak sebagai penangkal radikal bebas dan jika mempunyai gugus polihidroksi akan meningkatkan aktivitas antioksidan.

Sebelum larutan sampel diuji pada alat spektrofotometer UV-Vis, sampel diinkubasi terlebih dahulu pada suhu $37^{\circ} \mathrm{C}$ dengan cara menutup sampel dengan aluminium foil selama 30 menit. Pengujian aktivitas antioksidan diinkubasi pada suhu $37^{\circ} \mathrm{C}$ karena pada suhu ini reaksi antara radikal DPPH dengan senyawa metabolit sekunder berlangsung lebih optimal (Aji, 2014).

Berdasarkan penelitian yang telah dilakukan, penambahan larutan DPPH pada sampel ditandai dengan berubahnya warna ungu menjadi warna kuning yang berarti adanya proses penangkapan radikal bebas. Perubahan intensitas warna ungu ini terjadi karena adanya peredaman radikal bebas yang dihasilkan oleh bereaksinya molekul DPPH dengan atom hidrogen yang dilepaskan oleh molekul senyawa sampel sehingga menyebabkan terjadinya peluruhan warna DPPH dari ungu ke kuning. Menurut Saputri (2019), DPPH yang memiliki elektron tidak berpasangan akan memberikan warna ungu dan warnanya akan berubah menjadi kuning saat elektronnya telah berpasangan.

Pada pengujian aktivitas antioksidan, larutan DPPH kontrol berfungsi untuk mengetahui absorbansi radikal DPPH sebelum direduksi oleh sampel. Selisih antara absorbansi DPPH yang telah direduksi sampel dan absorbansi kontrol merupakan sisa radikal DPPH yang terbaca pada spektrofotometer UV-Vis. Menurut Meliendari (2012), semakin besar selisihnya maka semakin besar efektivitas antioksidan sampel. Absorbansi DPPH kontrol yang diperoleh yaitu 0,89 . Hasil pengujian aktivitas antioksidan dengan metode DPPH ditunjukkan pada Tabel 3.

Berdasarkan Tabel 3 diketahui bahwa bertambahnya konsentrasi sampel menyebabkan absorbansi sampel semakin menurun dan persen inhibisi meningkat. Hal ini dikarenakan terjadinya proses stokiometri reaksi reduksi senyawa radikal bebas DPPH oleh senyawa yang memberikan donor hidrogen sehingga DPPH menjadi senyawa yang stabil. Menurut Apak et al. (2004), senyawa aktif didalam ekstrak yang memiliki kemampuan penangkal radikal umumnya merupakan pendonor atom hidrogen $(\mathrm{H})$, sehingga atom $\mathrm{H}$ tersebut ditangkap oleh radikal DPPH (hidrazil) untuk berubah menjadi bentuk netralnya (hidrazin). Berdasarkan hasil yang diperoleh pada pengujian DPPH persen inhibisi pada ekstrak 
mengalami peningkatan pada konsentrasi

tertinggi yaitu $25 \mu \mathrm{g} / \mathrm{mL}$.

Tabel 3. Hasil Uji Antioksidan Estrak Biji Langsat dan Biji Duku

\begin{tabular}{|c|c|c|c|c|c|c|c|}
\hline \multirow[t]{2}{*}{ Sampel } & \multirow{2}{*}{$\begin{array}{c}\text { Konsen } \\
\text { trasi } \\
(\mu \mathrm{g} / \mathrm{mL})\end{array}$} & \multicolumn{3}{|c|}{ Absorbansi } & \multirow{2}{*}{$\begin{array}{l}\text { Rata- } \\
\text { rata }\end{array}$} & \multirow{2}{*}{$\begin{array}{c}\text { Inhibisi } \\
(\%)\end{array}$} & \multirow{2}{*}{$\begin{array}{c}\mathrm{IC}_{50} \\
(\mu \mathrm{g} / \mathrm{mL})\end{array}$} \\
\hline & & I & II & II & & & \\
\hline \multirow{5}{*}{$\begin{array}{l}\text { Ekstrak } \\
\text { Langsat }\end{array}$} & 5 & 0,601 & 0,578 & 0,565 & 0,58 & 34,83 & \multirow{5}{*}{57,69} \\
\hline & 10 & 0,538 & 0,582 & 0,595 & 0,57 & 35,95 & \\
\hline & 15 & 0,541 & 0,568 & 0,569 & 0,56 & 37,08 & \\
\hline & 20 & 0,542 & 0,539 & 0,546 & 0,54 & 39,32 & \\
\hline & 25 & 0,518 & 0,558 & 0,525 & 0,53 & 40,45 & \\
\hline \multirow{5}{*}{$\begin{array}{c}\text { Ekstrak } \\
\text { Duku }\end{array}$} & 5 & 0,606 & 0,570 & 0,585 & 0,59 & 33,67 & \multirow{5}{*}{31,40} \\
\hline & 10 & 0,525 & 0,575 & 0,601 & 0,57 & 35,93 & \\
\hline & 15 & 0,556 & 0,551 & 0,535 & 0,55 & 38,19 & \\
\hline & 20 & 0,495 & 0,532 & 0,541 & 0,52 & 40,90 & \\
\hline & 25 & 0,480 & 0,465 & 0,447 & 0,47 & 47,57 & \\
\hline \multirow{5}{*}{ Vit $\mathrm{C}$} & 5 & 0,572 & 0,570 & 0,549 & 0,56 & 37,08 & \multirow{5}{*}{8,03} \\
\hline & 10 & 0,326 & 0,328 & 0,328 & 0,33 & 62,92 & \\
\hline & 15 & 0,297 & 0,318 & 0,319 & 0,31 & 65,17 & \\
\hline & 20 & 0,213 & 0,185 & 0,173 & 0,19 & 78,65 & \\
\hline & 25 & 0,111 & 0,112 & 0,113 & 0,11 & 87,64 & \\
\hline
\end{tabular}

Nilai IC $_{50}$ ekstrak biji langsat, duku dan vitamin $\mathrm{C}$ didapat dari hasil perhitungan persamaan regresi linier. Variabel Y pada persamaan ini adalah sebagai $\mathrm{IC}_{50}$, sedangkan variabel $X$ pada persamaan ini adalah konsentrasi dari sampel yang akan dicari nilainya, dimana nilai dari $\mathrm{X}$ yang didapat merupakan besarnya konsentrasi yang diperlukan untuk dapat meredam 50\% aktivitas radikal DPPH. Berdasarkan data pada Tabel 3, diperoleh persamaan regresi untuk biji langsat, yaitu: $Y=33,143+0,2922 X$, sedangkan untuk biji duku, yaitu: $Y=29,421$ $+0,6554 \mathrm{X}$. Nilai $\mathrm{IC}_{50}$ dapat dihitung dari persamaan regresi linier yang sebelumnya telah diperoleh dengan mengganti $\mathrm{Y}$ dengan 50 pada persamaan tersebut. Nilai IC $_{50}$ merupakan suatu bilangan yang menunjukkan konsentrasi sampel uji yang mampu menghambat proses oksidasi sebesar $50 \%$. Menurut Zuhra et al. (2008), semakin kecil nilai $\mathrm{IC}_{50}$ menunjukkan semakin tinggi aktivitas antioksidan.

Berdasarkan penelitian yang telah dilakukan ekstrak biji langsat dan biji duku memiliki aktivitas antioksidan. Hasil pengujian aktivitas antioksidan ekstrak metanol biji langsat dan biji duku diperoleh nilai $\mathrm{IC}_{50}$ masing-masing sebesar 57,69 $\mu \mathrm{g} / \mathrm{mL}$ dan 31,40. Sedangkan aktivitas antioksidan vitamin $\mathrm{C}$ memiliki nilai $\mathrm{IC}_{50}$ sebesar 8,03 $\mu \mathrm{g} / \mathrm{mL}$, hasil tersebut menunjukkan bahwa ekstrak biji langsat memiliki aktivitas antioksidan yang kuat sedangkan ekstrak biji duku dan vitamin C yang digunakan sebagai pembanding termasuk antioksidan yang sangat kuat.

Menurut Marliana (2007) metabolit sekunder yang dapat berpotensi sebagai antioksidan, diantaranya adalah alkaloid, flavonoid, fenol, steroid, dan triterpenoid, sehingga dapat diketahui bahwa kandungan senyawa alkaloid, flavonoid dan triterpenoid pada ekstrak biji duku, berpotensi sebagai antioksidan yang sangat kuat dibandingkan dengan ekstrak biji langsat yang hanya terdapat senyawa alkaloid dan triterpenoid dengan aktivitas antioksidan kuat.

Senyawa alkaloid, terutama indol, memiliki kemampuan untuk menghentikan reaksi rantai radikal bebas secara efisien. Senyawa radikal turunan dari senyawa amina ini memiliki tahap terminasi yang sangat lama. Beberapa senyawa alkaloid lain yang bersifat antioksidan adalah quinolon, kafein yang dapat bertindak sebagai peredam radikal hidroksil dan melatonin yang berperan penting menjaga sel dari pengaruh radiasi dan toksisitas obat-obatan (Yuhernita \& Juniarti, 2011). Triterpenoid bertindak sebagai antioksidan karena memiliki rantai ikatan rangkap terkonjugasi sehingga elektronnya dapat disumbangkan untuk menstabilkan muatan molekul reaktif (Capelli \& Cisewsky, 2007). Flavonoid memiliki kemampuan antioksidan yang mampu mentransfer sebuah 
elektron ke senyawa radikal bebas dan membentuk kompleks dengan logam. Kedua mekanisme itu membuat flavonoid memiliki beberapa efek, diantaranya menghambat peroksidasi lipid, menekan kerusakan jaringan oleh radikal bebas dan menghambat beberapa enzim (Kandaswami \& Middleton, 1997).

\section{KESIMPULAN}

Skrining fitokimia pada ekstrak metanol biji langsat (Lansium domesticum var. pubescens) menunjukkan hasil positif terhadap alkaloid, triterpenoid dan saponin, sementara ekstrak metanol biji duku (Lansium domesticum var. domesticum) menunjukkan hasil positif terhadap alkaloid, flavonoid, tanin, triterpenoid dan saponin. Hasil pengujian aktivitas antioksidan ekstrak metanol biji langsat (Lansium domesticum var. pubescens) dan biji duku (Lansium domesticum var. domesticum) menggunakan metode DPPH diperoleh nilai $\mathrm{IC}_{50} \quad 57,69$ $\mu \mathrm{g} / \mathrm{mL}$ dan $31,40 \mu \mathrm{g} / \mathrm{mL}$. Ekstrak metanol biji langsat memiliki aktivitas antioksidan yang kuat dan ektrak metanol biji duku dan vitamin $\mathrm{C}$ murni yang memiliki aktivitas antioksidan yang sangat kuat.

\section{DAFTAR PUSTAKA}

Aji, R.M. 2014. Uji Aktivitas Antioksidan pada Ekstrak Daging Daun Lidah Buaya (Aloe vera) Menggunakan Metode DPPH (1,1-Diphenil-2Picrylhydrazyl) [Skripsi]. UIN Syarif Hidayatullah, Jakarta.

Aldi, P. 2013. Isolasi Dan Karakterisasi Senyawa Triterpenoid Dan Uji Antioksidan Dari Ekstrak Daun Duku (Lansium domesticum Corr). Diploma [Tesis], Universitas Andalas.

Apak, R., G.I. Kubilai, M. Zyrek \& S.E. Karademir. 2004. Novel total antioxidant capacity index for dietary poliphenols and vitamin $\mathrm{C}$ ang $\mathrm{E}$, using their cupric ion reducing in the presence neocuproine: cuprac method. J. Agric. Food Chem, 52(26): 79707981.

Blois, M.S. 2005. Antioxidant Determination by the Use of Stable Free Radical. Nature, 181: 1191-1200, Bogor.
Capelli, B. \& G. Cisewsky. 2007. Natural Antaxhantin: King of the Carotenoids. Cyanotech Corporation, Holualoa.

Darma, R.R. 2014. Isolasi Dan Karakterisasi Senyawa Metabolit Sekunder dari Fraksi Aktif Kulit Batang Duku (Lansium Domesticum Corr) Terhadap Brine Shrimps Lethality Bioassay. Diploma. [Thesis] , Universitas Andalas.

Halliwell, B. 2012. Free Radicals and Antioxidant: Updating a Personal View. Nutrition Review, 70(5): 257265.

Kadaswami, C. \& E. Middleton, Jr. 1997. "Flavonoid as Antioxidant". In: F. Shahidi. (Ed), Natural Antioxidants: Chemistry, Health Effects, and Applications. AOCS Press, Illionis.

Kopon A.M., A.B. Baunsele \& W.G. Boelan. 2020. Skrining Senyawa Metabolit Sekunder Ekstrak Metanol Biji Alpukat (Persea americana Mill.) Asal Pulau Timor. Akta Kimia Indonesia, 5(1): 43-52.

Lenny, S. 2006. Senyawa Flavanoida, Fenilpropanida dan Alkaloida. USU Press, Medan.

Liochev, S.I. 2013. Reaztive Oxygen Species and the Free Radical Theory of Aging. Free Radical Biology and Medicine, 60(1): 1-4.

Malangngi, L.P., M.S. Sangi \& J.J.E. Paendong. 2012. Penentuan Kandungan Tanin dan Uji Aktivitas Antioksidan Ekstrak Biji Buah Alpukat (Persea americana Mill.).

Marliana, E. 2007. Analisis Senyawa Metabolit Sekunder dari Batang Spatholobus ferrugineus (Zoll \& Moritzi) benth yang berfungsi sebagai antioksidan. Jurnal Penelitian MIPA, 1(1): 23-29.

McMurry, J. \& R.C. Fay. 2004. Chemistry $4^{\text {th }}$ Edition. Prentice Hall, New Jersey.

Meliendari, M. 2012. Uji Aktivitas Antioksidan Ekstrak Daun Gracia kyda Roxb. Dengan Metode DPPH dan Identifikasi Senyawa Kimia Fraksi yang Aktif [Skripsi]. Universitas Indonesia, Jakarta. 
Mokosuli, Y.S. 2008. Aktivitas antioksidan dan antikanker ekstrak kulit batang langsat (Lansium domesticum L.) [Tesis]. Sekolah Pascasarjana Institut Pertanian Bogor, Bogor.

Molyneux, P. 2004. The use of the stable free radical diphenylpicrylhydrazyl (DPPH) for estimating antioxidant activity., Songklanakarin Journal Science Technology, 26(2): 211-219.

Rizkayanti, R., A.W.M. Diah \& M.R. Jura. 2017. Uji Aktivitas Antioksidan Ekstrak Air dan Ekstrak Etanol Daun Kelor (Moringa Oleifera LAM). Jurnal Akademika Kimia, 6(2): 125131.

Robinson, T. 1995. Kandungan Organik Tumbuhan Obat Tinggi. Terjemahan Kosasih Padmawinata dan Iwang Soediro. ITB Press, Bandung.

Saputri, R. 2019. Uji Aktivitas Antioksidan Ekstrak Etanol Kulit Buah Mundar (Garcinia forbesii King.) Menggunakan Metode DPPH (2,2Diphenyl-1-Picrylhydrazil). Jurnal Pharmascience, 6(1): 74-82.

Selawa, W., M.R.J. Runtuwene, \& G. Citraningtyas. 2013. Kandungan Flavonoid dan Kapasitas Antioksidan Total Ekstrak Etanol Daun Binahong [Anredera cordifolia (ten.) steenis.]., Jurnal Ilmiah Farmasi Pharmacon, 2(1): 18-22.
Triyem. 2010. Aktivitas Antioksidan dari Kulit Batang Manggis Hutan (Garcina cf. Bancana Miq.) [Tesis]. Universitas Indonesia, Jakarta.

Umayah, E.U. \& Amrun. 2007. Uji Aktivitas Antioksidan Ekstrak Buah Naga (Hylocereus Undatus (Haw.) Britt. \& Rose). Jurnal Ilmu Dasar, 8(1): 83-90.

Watson, D.G. 2009. Analisis Farmasi Edisi ke-2. EGC, Jakarta.

Yu, L.L., H. Scott, P. Jonathan, H. Mary, W. John \& Q. Ming. 2002. Free Radical Scavenging Properties of Wheat Extracts. Journal Agriculture and Chemistry, 50(6): 1619-1624.

Yuhernita \& Juniarti. 2011. Analisis Senyawa Metabolit Sekunder Dari Ekstrak Metanol Daun Surian Yang Berpotensi Sebagai Antioksidan. Makara Sains, 15(1): 48-52.

Zou, Y., Y. Lu \& D. Wei. 2004. Antioxidant Activity of a Flavonoid-Rich Extract of Hypericum perforatum L. in Vitro. $J$. Agric. Food Chem, 52(16): 5032-5039.

Zuhra, C.F., J. Taringan \& H. Sihotang. 2008. Aktivitas Antioksidan Senyawa Flavonoid dari Daun Katuk (Sauropus androgumus (L) Merr.). Jurnal Biologi Sumatera, 3(1): 7-10.

Zulkarnain, H. 2017. Budidaya Buah-buahan Tropis. Deepublish, Yogyakarta. 